\title{
Cartel ringleaders and the corporate leniency program
}

\author{
Citation for published version (APA):
}

Bos, A. M., \& Wandschneider, F. (2011). Cartel ringleaders and the corporate leniency program. METEOR, Maastricht University School of Business and Economics. METEOR Research Memorandum No. 038 https://doi.org/10.26481/umamet.2011038

Document status and date:

Published: 01/01/2011

DOI:

10.26481/umamet.2011038

Document Version:

Publisher's PDF, also known as Version of record

\section{Please check the document version of this publication:}

- A submitted manuscript is the version of the article upon submission and before peer-review. There can be important differences between the submitted version and the official published version of record.

People interested in the research are advised to contact the author for the final version of the publication, or visit the DOI to the publisher's website.

- The final author version and the galley proof are versions of the publication after peer review.

- The final published version features the final layout of the paper including the volume, issue and page numbers.

Link to publication

\footnotetext{
General rights rights.

- You may freely distribute the URL identifying the publication in the public portal. please follow below link for the End User Agreement:

www.umlib.nl/taverne-license

Take down policy

If you believe that this document breaches copyright please contact us at:

repository@maastrichtuniversity.nl

providing details and we will investigate your claim.
}

Copyright and moral rights for the publications made accessible in the public portal are retained by the authors and/or other copyright owners and it is a condition of accessing publications that users recognise and abide by the legal requirements associated with these

- Users may download and print one copy of any publication from the public portal for the purpose of private study or research.

- You may not further distribute the material or use it for any profit-making activity or commercial gain

If the publication is distributed under the terms of Article $25 \mathrm{fa}$ of the Dutch Copyright Act, indicated by the "Taverne" license above, 


\section{Maastricht University}

I wan Bos, Frederick Wandschneider

Cartel Ringleaders and the Corporate Leniency Program

$\mathrm{RM} / 11 / 038$

\section{METEOR}

Maastricht University School of Business and Economics

Maastricht Research School of Economics

of Technology and Organization

P.O. Box 616

NL - 6200 MD Maastricht

The Netherlands 


\title{
Cartel Ringleaders and the Corporate Leniency Program*
}

\author{
Iwan Bos ${ }^{\dagger} \quad$ Frederick Wandschneider
}

August 1, 2011

\begin{abstract}
Cartel ringleaders can apply for amnesty in some jurisdictions (e.g., the E.U.), whereas in others they are excluded (e.g., the U.S.). This paper provides a survey of identified ringleaders in recent European cartel cases and explores theoretically the effect of ringleader exclusion on collusive prices. Our survey shows that $(i)$ cartels often had more than one ringleader, (ii) the role of ringleaders was very diverse and (iii) ringleaders were typically the largest cartel members. Our theoretical analysis reveals that ringleader exclusion leads to higher prices when $(i v)$ the joint profit maximum cannot be sustained under a nondiscriminatory leniency policy, $(v)$ antitrust fines depend on individual cartel gains in a nonlinear fashion and (vi) the size distribution of members is sufficiently heterogeneous. These findings support the imposition of antitrust penalties proportional to firm size when ringleaders are excluded from the corporate leniency program.
\end{abstract}

Keywords: Cartels; Leniency Program; Ringleader.

JEL classification: L1; L4.

\footnotetext{
${ }^{*}$ We appreciate the comments and suggestions of seminar participants at the University of East Anglia, University of Nottingham, CISS 2011 in Marmaris and the ZEW 2011 conference on Economic Methods in Competition Law Enforcement in Mannheim. We are particularly grateful to Panayiotis Agisilaou, Subhasish Modak Chowdhury, Steven Davies, Peter Ormosi and Andreas Stephan for very useful comments. All opinions and errors are ours alone.

${ }^{\dagger}$ Department of Organization \& Strategy, Maastricht University. Corresponding author at: P.O. Box 616, 6200 MD Maastricht, The Netherlands. E-mail: i.bos@maastrichtuniversity.nl.

${ }^{\ddagger}$ School of Economics and ESRC Centre for Competition Policy, University of East Anglia, Norwich NR4 7TJ, United Kingdom. E-mail: f.wandschneider@uea.ac.uk.
} 


\section{Introduction}

Corporate leniency programs around the world offer cartel members the opportunity to report their illegal conduct in exchange for full immunity or a reduction of antitrust penalties. Although the various programs across jurisdictions have many similarities, the treatment of undertakings that had a central role in establishing or organizing the cartel differs markedly. Most notably, such "cartel ringleaders" are sometimes eligible for amnesty (e.g., in Europe), whereas in other jurisdictions they are excluded from the leniency program (e.g., in the U.S.). The purpose of this paper is to gain understanding of cartel ringleaders and how ringleader exclusion may affect collusion.

Before proceeding, it is important to clarify what we mean by the terms "cartel ringleader" and "ringleader exclusion". Towards that end, let us first have a closer look at the leniency policy regarding ringleaders in both the U.S. and Europe. To begin, the 1993 U.S. guidelines on corporate leniency uses a hybrid leader/coercer standard, which reads that a firm is only eligible for amnesty when it "did not coerce another party to participate in the illegal activity

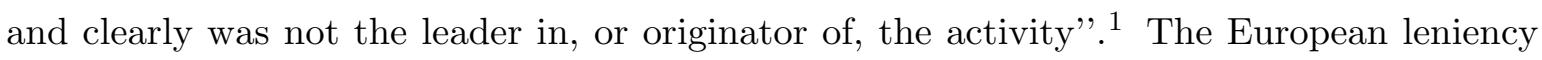
program became effective in 1996 and initially followed the U.S. approach rather closely. Only a firm that "has not compelled another enterprise to take part in the cartel and has not acted as an instigator or played a determining role in the illegal activity" can obtain non-imposition or a (very) substantial reduction of fines. ${ }^{2}$ This standard significantly restricted ringleaders by only allowing them to apply for a limited fine reduction in the range of 10 to $50 \%$.

However, and in contrast to the original 1996 leniency notice, the 2002 and 2006 revisions allow ringleaders to apply for full immunity provided that some standard requirements are met. ${ }^{3}$ To increase legal certainty and clarity about what it means to have a "determining role", the Commission further distinguishes between instigation and leadership. The former concerns the establishment or enlargement of a cartel, whereas the latter applies to its operation. ${ }^{4}$ More specifically, an instigator is an undertaking that has persuaded or encouraged other firms to establish or join a cartel by taking the initiative to suggest collusion. A firm is classified as a leader if it was a significant driving force for the cartel. This may include voluntarily giving a major boost to the performance of the cartel by being the first firm to implement

\footnotetext{
${ }^{1}$ United States Department of Justice (1993), Corporate Leniency Policy, para A6. See also B7.

${ }^{2}$ European Commission (1996), Commission Notice on the non-imposition or reduction of fines in cartel cases, para B(e).

${ }^{3}$ European Commission (2002), Commission notice on immunity from fines and reduction of fines in cartel cases, para A11(c) and Section B.

${ }^{4}$ See Case T-15/02 BASF AG v. Commission, Summary of the Judgement, March 15, 2006; side numbers 14-18.
} 
the arrangement, taking voluntary initiatives to propel the cartel and, more generally, by taking responsibility for developing the illegal agreement. Exerting pressure ("coercion") or dictating behavior itself is not a necessary precondition to be described as a "leader". 5 Being a significant driving force of the cartel is sufficient, even when the power to impose the agreement on other undertakings is lacking. ${ }^{6}$

In the ensuing analysis, we use the term "ringleader" broadly in that we do not make an explicit distinction between instigation and leadership. As to ringleader exclusion, we distinguish between a "non-discriminatory leniency program" and a "discriminatory leniency program". The former is used to describe the case where ringleaders have the same rights as regular cartel members, whereas the latter refers to a situation where ringleaders are not eligible for (full) immunity.

Understanding the impact of ringleader exclusion on collusion is not trivial. On the one hand, knowing ex ante which of the cartel members is not eligible for amnesty is likely to affect the level of trust among colluders. In particular, the fact that a ringleader has not much to gain from self-reporting makes it a trustworthy "partner in crime". Indeed, in a review of the U.S. corporate leniency program, Leslie (2006) argues in favor of a nondiscriminatory leniency program as this would foster distrust among cartel participants. Moreover, ringleader exclusion increases the chance for regular cartel members to be the first to self-report, which in turn lowers the risk of a "race to the courtroom", all else equal. On the other hand, ringleader exclusion increases the expected antitrust penalty for ringleaders, thereby making collusion less attractive. ${ }^{7}$ Also, firms are likely to have a stronger incentive to wait for others to take the lead, which makes the formation of cartels ceteris paribus less likely. Finally, ringleader exclusion introduces legal uncertainty as it may not always be clear when a firm is regarded a leader. This unclarity potentially leads to fewer confessions. It is therefore a priori unclear whether ringleader exclusion enhances deterrence or instead facilitates collusion.

In this paper, we seek to shed some light on how ringleader exclusion affects collusion. As not much is known about cartel ringleaders, we first provide a survey of 75 fining decisions taken by the European Commission between 2000 and 2010. In 14 cases, leadership is identified and explicitly mentioned as an aggravating circumstance. A detailed analysis of these cases

\footnotetext{
${ }^{5}$ Coercers cannot obtain full immunity, although firms "which took steps to coerce other undertakings to join the cartel or to remain in it (...) may still qualify for a reduction of fines (...)". See European Commission (2006), Commission notice on immunity from fines and reduction of fines in cartel cases, para A13.

${ }^{6}$ Case T-15/02 BASF AG v. Commission, March 15, 2006; para 374.

${ }^{7}$ Apart from being (partially) excluded, ringleaders additionally face an increase of the basic fine. See European Commission (2006), Guidelines on the method of setting fines imposed pursuant to Article 23(2)(a) of Regulation No 1/2003, para A28 and United States Sentencing Commission (2010), Guidelines Manual, para 3B1.1.
} 
reveals, among other things, that $(i)$ cartels often had more than one ringleader, $(i i)$ the role of ringleaders was very diverse and (iii) ringleaders were typically the largest cartel members. Next, we theoretically analyze the impact of ringleader exclusion on the collusive price level. Specifically, we analyze a price setting supergame in which firms differ in terms of capacity stocks, which is taken as a proxy for firm size. Under the assumption that cartel profits as well as the (expected) antitrust penalty depend positively on firm size, we find that a discriminatory leniency program leads to higher prices when $(i v)$ the joint profit maximum cannot be sustained under a nondiscriminatory leniency policy, $(v)$ antitrust fines depend on individual cartel gains in a nonlinear fashion and $(v i)$ the size distribution of members is sufficiently heterogeneous. ${ }^{8}$ We also consider the possibility of alternative profit allocation rules and establish that side-payments are ceteris paribus most likely when the intended ringleader is the smallest firm. Our overall findings therefore support the imposition of antitrust penalties proportional to firm size when ringleaders are excluded from the corporate leniency program.

Despite the growing literature on leniency, little is known about cartel ringleaders and the impact of ringleader exclusion on collusion. ${ }^{9}$ To our knowledge, the only other paper that explicitly and extensively analyzes cartel ringleaders in relation to the corporate leniency program is Herre and Rasch (2009). This study theoretically explores the deterrent effect of ringleader exclusion by considering variations in the probability of conviction. If there is a relatively small chance of being caught, then a non-discriminatory leniency policy is preferred as the additional information that a ringleader may provide can be essential for cartel prosecution. By contrast, if the probability of conviction is relatively high, then it is optimal to exclude ringleaders. The reason is that ringleader exclusion creates an asymmetry among firms, which makes sustainability of collusion ceteris paribus more difficult.

This paper proceeds as follows. The next section provides a description and discussion of cartel ringleaders in antitrust practice. The model is introduced in Section 3. Section 4 provides a benchmark by analyzing collusion under a nondiscriminatory leniency policy. Section 5 explores the impact of ringleader exclusion on the collusive price level and investigates incentives to compensate the ringleader for its loss in expected leniency discount. Section 6 concludes.

\footnotetext{
${ }^{8}$ In a recent experimental study by Bigoni, Fridolfsson, Le Coq and Spagnolo (2009) it is found that ringleader exclusion leads to higher prices, but hardly affects the formation of cartels.

${ }^{9}$ Contributions in this area include, among others, Motta and Polo (1999, 2003), Spagnolo (2000), Aubert, Rey and Kovacic (2006), Motchenkova and Leliefeld (2007), Harrington (2008) and Miller (2009). For a recent overview and discussion of research on leniency, see Spagnolo (2008).
} 


\section{Cartel Ringleaders in Practice}

Before analyzing the impact of ringleader exclusion on collusion, we believe it is instructive to first examine cartel ringleaders in practice. Towards that end, we have conducted a survey of 75 European Commission cartel decisions taken over the last decade. Specifically, we have surveyed all prohibition decisions and press releases concerning the policy area "Cartels" between January 1, 2000 and January 1, 2011. ${ }^{10}$ For each case, we first assessed whether the European Commission explicitly mentions the leading role of one or more cartel members and adjusted the fine accordingly. This happened in 14 out of the total of 75 cases. Next, we have analyzed these 14 cases in detail. Table 1 provides an overview of the identified ringleader cases. Together with the case title and the name of the identified ringleaders, it shows the number of firms involved in the infringement and how many firms were identified as having a leading role. It further states whether or not the largest member in terms of market shares was a ringleader. The last two columns list, respectively, the fine increase due to leadership and the granted leniency reduction.

Before we proceed, a word of caution is in order. We are aware that the findings presented here may be biased in several respects. First, and inherent to all empirical cartel studies, our sample of cartel cases may not be a good representation of the unknown pool of cartels. Second, our sample might be a fraction of the actual number of ringleader cases. As leadership typically results in a substantial increase of the antitrust fine (for our sample, the average fine increase is about $42 \%$ ), the Commission is likely to explicitly refer to a leading role only when it has sufficient legal evidence available to win an appeal in court. Our sample is therefore likely to mark a lower bound as there may have been other cases in which the Commission, despite having some evidence of leadership, did not increase the base fine. Finally, the vast majority of ringleader cartels operated in manufacturing industries producing more or less homogeneous goods; one of which included agreements between buyers and sellers (Bitumen Nederland). It can be argued that such a buyer - seller cartel has different structural features compared to horizontal cartel agreements.

This being said, we are confident that a discussion of some of the traits of known cartel ringleaders is informative and may serve as a basis for current and future research. In the following, we present some stylized facts, discuss the role of the ringleader and assess the impact of leadership on the antitrust penalty.

\footnotetext{
${ }^{10}$ These dates were chosen rather arbitrarily. We do not expect results to be radically different for alternative time frames. For the selected period, we have studied all cases that were available at the Commission's online database at the end of March 2011 (See http://ec.europa.eu/competition/cartels/cases/cases.html). For those interested in our complete dataset, please contact one of the authors.
} 


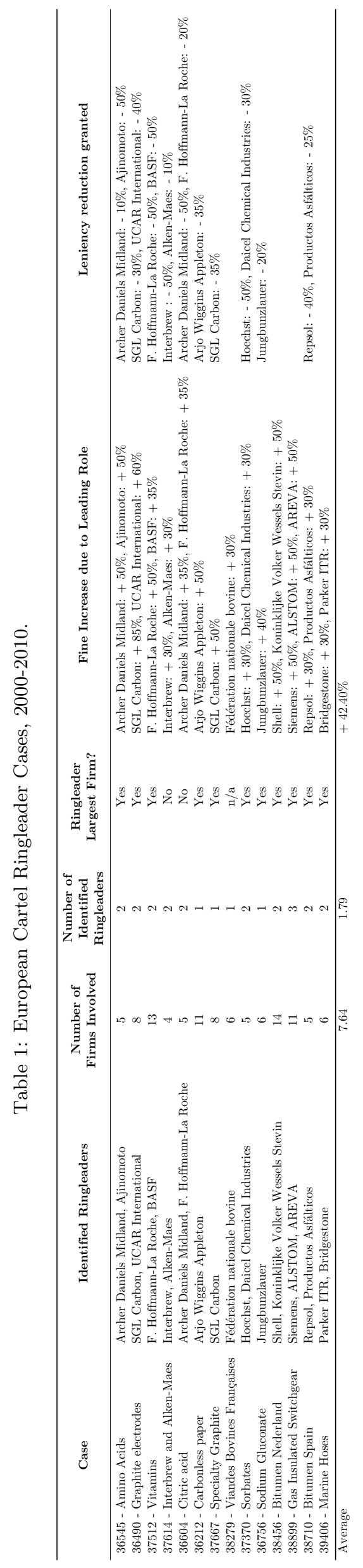




\subsection{Some Stylized Facts}

As can be seen in Table 1, most of the ringleader cartels had more than one ringleader. Specifically, two or more undertakings shared the responsibility for establishing or leading the cartel in 10 out of 14 cases. Some cartels had multiple ringleaders operating simultaneously, whereas in other cases members took turns. Four cartels were led by a single undertaking and the majority had two ringleaders (the average number of leaders is 1.79). One cartel had three leading participants, but this case is somewhat special. In Gas Insulated Switchgear, Siemens was the sole leader during most of the cartel's life. ALSTOM replaced Siemens during its temporary departure from the cartel and this firm was taken over at some point by AREVA, which continued the leading role.

As Table 1 reveals, the number of ringleaders does not seem to be correlated with the number of cartel participants. For instance, in Carbonless paper there were eleven members and one ringleader, whereas in Interbrew and Alken-Maes there were four members and two leaders. The average number of firms involved in a cartel with one, two or three identified ringleaders is respectively $7.75,7.22$ and 11 . These averages do not seem to be notably different from average cartel sizes reported in other studies.

Another characteristic of ringleaders concerns their market position. In at least $79 \%$ of the cases, the largest firm in terms of market shares was one of the ringleaders. This finding is supported by Ganslandt, Persson and Vasconcelos (2010) which establishes that ringleaders are frequently substantially larger than other firms. There are two cases for which this was not true. Yet, in one of these cases, Interbrew and Alken-Maes, the ringleaders were in fact the two largest brewers in Belgium, but not in the market segment where the cartel was active (Belgian private label beer). Likewise, the ringleaders in Citric acid were the world's biggest vitamin producers, but not in the relevant market segment. A third case, Viandes Bovines Françaises, had the association of farmers as a ringleader, which makes it difficult to use market shares as a measure of market power. Moreover, it is noteworthy that in Gas Insulated Switchgear, the largest firm was indeed a ringleader but this firm temporarily left the cartel, which left space for a smaller producer to take the lead.

\subsection{Role of the Ringleader}

The role of ringleaders varied remarkably among the cartels and often consisted of a mixture of activities related to instigation and leadership. As to instigation, the most common activity was to encourage other companies to join the cartel. Specifically, in 6 out of 14 cases the ringleader approached other companies in order to persuade them to join the agreement. In 
some of these cases, the ringleader explained the mechanisms of the cartel and highlighted the added value of previous arrangements. Surprisingly, coercion seems to have played a minor role. In only three cases, there was sufficient evidence that leaders (ab)used their dominant market position to discipline unwilling undertakings. ${ }^{11}$

Activities concerned with the operation of the cartel ("Leadership") can be categorized in four main tasks. First, in 10 out of 14 cases, leaders were the first to implement a collusive agreement or to announce price changes. For example, in Vitamins, BASF and F. Hoffmann-La Roche took turns in announcing price changes and then invited the other cartel participants to follow. This finding confirms recent theoretical predictions about collusive price leadership. For instance, Ishibashi (2008) establishes that under price competition with capacity constraints larger firms have an incentive to move early. Moreover, Mouraviev and Rey (2011) show that price leadership can facilitate collusion by allowing for more effective punishments. Second, leaders exercised tasks intended to enhance the operation of the cartel. This includes manning the cartel secretariat, collecting commercial information and exchanging summaries, providing presentations about the state of the industry or allocating customers. In Marine Hoses, for example, Bridgestone allocated tenders to cartel members and provided bidding instructions and tables indicating the actual state of tender allocation. Third, in 9 out of 14 cases, the leader's task was to organize the actual communication. Among other things, this includes hosting, organizing or chairing meetings, paying bills and setting up the agenda. In Sorbates, for instance, Hoechst hosted, organized and payed for the European cartel meetings. Finally, in 6 cases, the ringleader acted as a representative or intermediary. In Bitumen Nederland, KWS and Shell were both representatives of either buyer or seller groups and often negotiated bilaterally to reach outcomes that were 'binding' for the other participants. In Sodium Gluconate, Jungbunzlauer negotiated between members in case of internal rivalry.

Other activities were more specific to the need of the respective cartel. For instance, in Gas Insulated Switchgear part of the leading role of Siemens was to provide European and Japanese fellow members with Siemens mobile phones equipped with encryption technology.

\subsection{Ringleaders and the Antitrust Penalty}

The European Commission rules that a firm that takes the role of a leader or instigator bears a special responsibility, which may result in an increase of the basic fine. We find that, once leadership or instigation was identified as an aggravating circumstance, ringleaders indeed

\footnotetext{
${ }^{11}$ See Marshall, Marx and Samkharadze (2011) for a description and analysis of dominant-firm conduct by cartels.
} 
received an increase of the basic fine in the range of $30 \%$ to $85 \%$. The average fine increase is about $42 \%$. In five cases, a ringleader asked for non-imposition or a substantial reduction (> 50\%) of its fine under the 1996 leniency notice. However, these requests were rejected with reference to their leading role. Overall, the leader received a significant reduction of the fine in the range of $10 \%$ to $50 \%$ in ten cases.

The increase in fines due to leadership as well as their right to apply for leniency is a topic of heated debate, in particular when there is more than one ringleader involved. In case of multiple ringleaders, the Commission recognizes that:

"...it could be argued that, in relation to each other, leaders are co-equals, and that in such a context none of the leaders is able to play a determining role in the infringement. This would also provide an incentive for leaders in the infringement to come forward first and to adduce decisive evidence of the cartel's existence. However, from the wording of the leniency notice it is clear that the Commission balanced the Community interest in granting favourable treatment to offenders which cooperate with it against the Community interest to deter future offenders by fining undertakings for their committed infringements. This balance would be disturbed if leniency was available for cartel members which played a determining role in the infringement." 12

In Specialty Graphite, the Commission increased the fine for SGL Carbon by 50\%. SGL Carbon challenged this outcome as it felt that the weight given to its leading role was disproportionate. The Commission, however, justified its decision by stating that it has "no obligation to apply a mathematical formula nor is it generally bound by previous decisions" ${ }^{13}$

\section{Model}

To explore the potential impact of ringleader exclusion on collusion, we study a modified version of the price setting supergame with capacity constraints as presented in Bos and Harrington (2010). Consider a homogeneous good industry in which a fixed and finite set of firms, denoted by $N=\{1, \ldots, n\}$, interact repeatedly over an infinite, discrete time horizon. Producers have constant unit cost $c \geq 0$ and choose prices from $\{0, \epsilon, 2 \epsilon, \ldots, c-\epsilon, c, c+\epsilon, \ldots\}$

\footnotetext{
${ }^{12}$ Case COMP/36.545/F3 Amino acids, paras 418 and 419. Interestingly, in the U.S. it holds that "in situations where the corporate conspirators are viewed as co-equals or where there are two or more corporations that are viewed as leaders or originators, any of the corporate participants will qualify" for amnesty under the U.S. guidelines. See U.S. Department of Justice (1998), The Corporate Leniency Policy: Answers to Recurring Questions.

${ }^{13}$ Case T-71/03 Tokai Carbon and Others v. Commission, paras 310 and 315.
} 
with $\epsilon$ being small and positive. In each period, firms simultaneously make price decisions so as to maximize the expected discounted sum of their profit stream, where $\delta \in(0,1)$ is the common discount factor. There is perfect monitoring in the sense that prices chosen in previous periods are common knowledge. The production capacity of firm $i \in N$ is denoted by $k_{i}$ and we assume that $k_{1} \geq k_{2} \geq \ldots \geq k_{n}$, which is without loss of generality. Total industry capacity is $K=\sum_{i \in N} k_{i}$ and capacity stocks remain fixed throughout the entire game.

Market demand is given by $D(p)$, which we assume to be twice continuously differentiable with $D^{\prime}(p)<0$ and $D^{\prime \prime}(p) \leq 0$. Moreover, $D(c)>0$ and monopoly profit, $(p-c) D(p)$, is strictly concave. The monopoly price is denoted by $p^{m}: D\left(p^{m}\right)+\left(p^{m}-c\right) D^{\prime}\left(p^{m}\right)=0$. Consumers buy first from the cheapest supplier(s). Demand of firm $i$ is then given by $D_{i}\left(p_{i}, \mathbf{p}_{-\mathbf{i}}\right)$, which depends on its own price $p_{i}$ and the prices set by all rivals $\mathbf{p}_{-\mathbf{i}}$. Following Bos and Harrington (2010), we make the following simplifying assumption on firms' capacities.

Assumption 1. $k_{i}<D\left(p^{m}\right)$ and $\sum_{j \in N \backslash\{i\}} k_{j} \geq D(c)$, for all $i \in N$.

The first part of Assumption 1 states that each firm has insufficient capacity to supply monopoly demand. Thus, the possibility of producers being very large in absolute terms is ruled out. Yet, they can be of significant size in relative terms. The second part states that any $n-1$ firms can meet competitive demand. Indeed, the second part of Assumption 1 implies that there are two (symmetric) Nash equilibria in the one-shot game. The static Nash equilibrium has all firms either pricing at $c$ or at $c+\epsilon$. However, as results will be derived for sufficiently small $\epsilon$, this difference is negligible. As a consequence, producers make zero profits absent collusion. A final implication of Assumption 1 is that duopolistic market structures are excluded (i.e., $n \geq 3$ ). Albeit somewhat restrictive, it holds for the majority of industries in which collusive behavior has been observed. ${ }^{14}$ For example, the cartels discussed in Section 2 above all operated in markets with more than three undertakings. Moreover, cartels comprising two members form a special case when considering ringleader exclusion as the presence of a ringleader would eliminate the "race to the courtroom".

Firms can potentially improve profitability by coordinating on a common price $p>c+\epsilon$. In the following, we consider the formation of an all-inclusive cartel and assume that collusive profits are divided according to a proportional allocation rule. ${ }^{15}$ Cartel profits are therefore

\footnotetext{
${ }^{14}$ A notable exception is the cartel agreement between auction houses Christie's and Sotheby's in the 1990s. See Case COMP/E-2/37.784, Fine Art Auction Houses.

${ }^{15}$ Bos and Harrington (2010) provides various rationales for a proportional profit sharing rule. For instance, capacity may be taken as a proxy for market share and there exists evidence of cartels that based their profit sharing rule on the market share of members in years prior to the cartel.
} 
given by

$$
\pi_{i}(p)=(p-c) D(p) \frac{k_{i}}{K}, \text { for all } i \in N
$$

Yet, by doing so, firms expose themselves to antitrust enforcement. There is a risk of being caught after each collusive period and, for simplicity, it is assumed that conviction leads to a permanent breakdown of the cartel. Let the probability of conviction be given by $\alpha \in(0,1)$. Leaving out the potential discount due to leniency (which we will introduce below), successful cartel prosecution has firm $i$ paying a fine $F\left(k_{i}\right)$. We make the following assumption on the penalty function $F(k)$.

Assumption 2. The antitrust penalty function $F(k)$ is continuously differentiable with $F(0)=0$ and $F^{\prime}(k)>0$ at all $k \in\left(0, D\left(p^{m}\right)\right)$.

Assumption 2 states that larger firms incur a higher fine in case of conviction, all else equal. Moreover, as we assume a proportional allocation rule, fines are positively correlated with cartel gains. This seems to be a plausible assumption for many jurisdictions. For instance, the European Commission's 2006 fining guidelines prescribe the use of the value of sales to determine the fine. More specifically, the basic fine is computed as a proportion of the value of sales in the last business year before taxes while taking account of the gravity and duration of the infringement. In a similar vein, the U.S. penalty guidelines offer a way to determine the basic fine using the pecuniary loss due to the offense for which $20 \%$ of the volume of affected commerce (i.e., total U.S. sales revenue) is used as a proxy. Depending on several factors (e.g., criminal history or cooperation with the authorities), the fine may be multiplied with a culpability factor which can yield an increase of up to $80 \%$ of the volume of commerce. As the precise determination of antitrust penalties is complex and varies among jurisdictions, we do not further specify the antitrust penalty function.

\section{Nondiscriminatory Leniency: A Benchmark}

In this section, we introduce and analyze the cartel's problem under the assumption that a ringleader can apply for leniency like regular cartel members. We require collusion to be a subgame perfect Nash equilibrium outcome of the game and assume that firms adopt grim-trigger strategies to sustain supra-competitive prices. That is, every member of the cartel adheres to the collusive agreement until one firm deviates. In the event of defection, the coalition collapses with a one-period time lag and all firms set stage game Nash equilibrium 
prices in all periods following the period of defection. ${ }^{16}$ For ease of analysis, we assume that all members ex ante have identical expectations about the amount of discount they might receive due to leniency. Let this expected discount be captured by a parameter $\beta \in(0,1)$. Specifically, higher values of $\beta$ correspond to larger expected reductions of the antitrust fine, all else equal.

Under this nondiscriminatory antitrust regime, the collusive value for firm $i$ is defined recursively by

$$
V_{i}(p)=(p-c) D(p) \frac{k_{i}}{K}+\delta\left((1-\alpha) V_{i}(p)-\alpha(1-\beta) F\left(k_{i}\right)\right),
$$

which is equivalent to

$$
V_{i}(p)=\frac{(p-c) D(p) \frac{k_{i}}{K}-\delta \alpha(1-\beta) F\left(k_{i}\right)}{1-\delta(1-\alpha)} .
$$

If a cartel member deviates from the cartel agreement, then it will optimally set a price $p-\epsilon$. This is so, as by Assumption 1 the cheating firm produces up to capacity. Consequently, further lowering prices is unprofitable. We assume that once a firm deviates, it cannot be convicted for its former misconduct. ${ }^{17}$ Therefore, given that the price grid is sufficiently fine, optimal deviating profits are approximately equal to $(p-c) k_{i}$.

The incentive compatibility constraint (ICC) under a nondiscriminatory leniency regime is then given by

$$
\frac{(p-c) D(p) \frac{k_{i}}{K}-\delta \alpha(1-\beta) F\left(k_{i}\right)}{1-\delta(1-\alpha)} \geq(p-c) k_{i}, \text { for all } i \in N .
$$

Rearranging gives,

$$
\lambda_{i}(p) \equiv(p-c)\left(\frac{D(p)}{K}-1+\delta(1-\alpha)\right)-\delta \alpha(1-\beta) \frac{F\left(k_{i}\right)}{k_{i}} \geq 0, \text { for all } i \in N .
$$

Let us have a closer look at the ICC's as given by (5). First observe that (5) is violated for $p=c$. Colluding on prices sufficiently close to unit production costs is therefore not feasible, which is due to the antitrust penalty. Next, the LHS of (5) is strictly concave:

$$
\lambda_{i}^{\prime \prime}(p)=\frac{2 D^{\prime}(p)+(p-c) D^{\prime \prime}(p)}{K}<0 .
$$

For collusion to be feasible, this implies that the first order condition at $c$ must be positive. Taking the derivative of $\lambda_{i}(p)$ gives:

$$
\lambda_{i}^{\prime}(p)=\frac{D(p)+(p-c) D^{\prime}(p)}{K}-1+\delta(1-\alpha) .
$$

\footnotetext{
${ }^{16}$ Note that the grim-trigger strategy is the most severe credible threat in this setting. That is to say, whenever some level of collusion cannot be sustained by the threat of eternal competition, then it cannot be sustained by any other credible punishment strategy.

${ }^{17}$ Allowing for antitrust enforcement after defection would complicate the analysis, but does not qualitatively affect the results.
} 
Thus, a necessary condition for collusion is $\lambda_{i}^{\prime}(c)>0$ or $\delta>\frac{K-D(c)}{(1-\alpha) K}$. Feasibility of collusion therefore requires that firms are sufficiently patient and that the probability of getting caught is not too high. ${ }^{18}$

As monopoly profit is strictly concave, (3) reveals that all cartel members agree to maximize the cartel price (not exceeding the monopoly price). Therefore, the cartel faces the following constrained maximization problem:

$$
\max _{p}(p-c) D(p)
$$

subject to

$$
\lambda_{i}(p) \geq 0, \text { for all } i \in N \text {. }
$$

Clearly, the cartel will optimally set the monopoly price when $\lambda_{i}\left(p^{m}\right) \geq 0$ for all $i \in N$. However, the monopoly price may not be sustainable. To see this, notice that $\lambda_{i}^{\prime}\left(p^{m}\right)=$ $-1+\delta(1-\alpha)<0$ and therefore $\lambda_{i}(p)$ reaches its maximum at a price below the monopoly price. Consequently, collusion may be feasible only at a price below the monopoly price. In the following, let $p^{*} \equiv \min \left[\bar{p}, p^{m}\right]$ denote the solution to (6), where $\bar{p}$ is the constrained solution.

Given that collusion is sustainable but not at the monopoly price, the issue to consider is which firm has the binding ICC. The next result shows that this effectively depends on the shape of the antitrust penalty function.

Lemma 3. Suppose $k_{j}>k_{i}$.

(i) If $F^{\prime}(k)<\frac{F(k)}{k}$, then $\lambda_{j}(p)>\lambda_{i}(p)$,

(ii) If $F^{\prime}(k)=\frac{F(k)}{k}$, then $\lambda_{j}(p)=\lambda_{i}(p)$, and

(iii) If $F^{\prime}(k)>\frac{F(k)}{k}$, then $\lambda_{j}(p)<\lambda_{i}(p)$.

Proof With a non-discriminatory leniency program, the incentive compatibility constraint of each cartel member is of the following form:

$$
(p-c)\left(\frac{D(p)}{K}-1+\delta(1-\alpha)\right)-\delta \alpha(1-\beta) \frac{F(k)}{k} \geq 0 .
$$

Taking the derivative with respect to $k$ yields

$$
\frac{k\left(-\delta \alpha(1-\beta) F^{\prime}(k)\right)-(-\delta \alpha(1-\beta) F(k))}{k^{2}} \lesseqgtr 0 .
$$

Rearranging gives,

$$
F(k)-k F^{\prime}(k) \lesseqgtr 0 .
$$

\footnotetext{
${ }^{18}$ Observe that the ICC's are satisfied when $\delta \rightarrow 1$ and $\alpha \rightarrow 0$.
} 
Hence, at any price $p$ : (i) if $F^{\prime}(k)-\frac{F(k)}{k}<0$, then $\lambda(p)$ is highest for the largest firm(s), (ii) if $F^{\prime}(k)-\frac{F(k)}{k}=0$, then $\lambda(p)$ is equal for all cartel members, and (iii) if $F^{\prime}(k)-\frac{F(k)}{k}>0$, then $\lambda(p)$ is highest for the smallest firm(s).

Part $(i)$ states that the smallest member has the tightest ICC when the antitrust penalty function is concave. Part ( $i i$ ) shows that all firms face the same ICC when the fining structure depends on firm size in a linear fashion. Part ( $i i i)$ states that the largest member has the tightest ICC when the antitrust penalty function is convex.

\section{The Impact of Ringleader Exclusion}

In this section, we evaluate the potential impact of ringleader exclusion on the collusive price level and assess whether it provides incentives to compensate the ringleader for its loss in expected leniency discount. We will show that a discriminatory leniency program leads to higher prices when $(i)$ the monopoly price cannot be sustained under a nondiscriminatory leniency policy, (ii) antitrust fines depend on individual cartel gains in a nonlinear fashion, and ( iii) the size distribution of members is sufficiently heterogeneous. Additionally, we find that adopting a different profit sharing rule is most likely when the intended ringleader is the smallest firm. In light of available evidence from antitrust practice, we consider the use of side-payments to compensate the ringleader possible but rather unlikely.

\subsection{Collusive Price Level}

To begin, suppose the cartel has a ringleader that is not (or only partly) eligible to apply for leniency. An effect of such a discriminatory leniency policy, when compared to the benchmark, is that the expected discount for regular cartel members increases, whereas it decreases for the ringleader. This asymmetry is due to the fact that the ringleader is excluded from (full) immunity and therefore will be less eager to apply for leniency. In turn, this ceteris paribus increases the chance for regular members to win the "race to the courthouse", thereby increasing the expected discount. Let the expected discount for the ringleader and regular members under a discriminatory leniency program be respectively given by $\beta_{l}$ and $\beta_{m}$, with $0 \leq \beta_{l}<\beta<\beta_{m}<1$. Thus, moving from a nondiscriminatory to a discriminatory leniency program loosens the ICC of regular cartel members and tightens the ICC of the ringleader, all else equal. This implies that in order to assess the impact of ringleader exclusion on the 
collusive price level it is sufficient to evaluate the change in the ICC of the ringleader. ${ }^{19}$

In the following, let $l$ indicate the ringleader and let $k_{l}$ denote its production capacity. The ringleader's ICC is thus given by

$$
\lambda_{l}(p) \equiv(p-c)\left(\frac{D(p)}{K}-1+\delta(1-\alpha)\right)-\delta \alpha\left(1-\beta_{l}\right) \frac{F\left(k_{l}\right)}{k_{l}} \geq 0 .
$$

The next result shows under which conditions a discriminatory leniency policy leads to higher prices compared to a nondiscriminatory leniency policy. In stating this result, let $p^{* *}$ denote the optimal price of the cartel with a ringleader under a discriminatory leniency regime. Additionally, define the tightest ICC under a nondiscriminatory leniency policy as $\bar{\lambda}(p) \equiv \min \left\{\lambda_{1}(p), \ldots, \lambda_{n}(p)\right\}$ and let $\bar{k}$ be the capacity level for which $\bar{\lambda}\left(p^{*}\right)=0$.

Theorem 4. Suppose that there is a ringleader and that collusion is viable under a nondiscriminatory leniency policy. $p^{* *}>p^{*}$ if and only if $p^{*}<p^{m}$ and

$$
\frac{(1-\beta)}{\left(1-\beta_{l}\right)}>\frac{\frac{F\left(k_{l}\right)}{k_{l}}}{\frac{F(\bar{k})}{\bar{k}}} .
$$

Proof First, notice that the cartel does not find it optimal to set a price in excess of the monopoly price. Consequently, if $p^{*}=p^{m}$, then $p^{* *} \leq p^{*}$. Suppose therefore that $p^{*}<p^{m}$, which implies $\bar{\lambda}\left(p^{*}\right)=0$. As ringleader exclusion loosens the ICC of regular members and tightens the ICC of the ringleader, $p^{*}$ is sustainable under a discriminatory leniency regime when $\lambda_{l}\left(p^{*}\right) \geq \bar{\lambda}\left(p^{*}\right)$. If $\lambda_{l}\left(p^{*}\right)<\bar{\lambda}\left(p^{*}\right)$, then $p^{* *}<p^{*}$. Likewise, $p^{* *}>p^{*}$ when $\lambda_{l}\left(p^{*}\right)>\bar{\lambda}\left(p^{*}\right)$, or

$$
\left(p^{*}-c\right)\left(\frac{D\left(p^{*}\right)}{K}-1+\delta(1-\alpha)\right)-\delta \alpha\left(1-\beta_{l}\right) \frac{F\left(k_{l}\right)}{k_{l}}>\left(p^{*}-c\right)\left(\frac{D\left(p^{*}\right)}{K}-1+\delta(1-\alpha)\right)-\delta \alpha(1-\beta) \frac{F(\bar{k})}{\bar{k}} .
$$

Rearranging gives

$$
\frac{(1-\beta)}{\left(1-\beta_{l}\right)}>\frac{\frac{F\left(k_{l}\right)}{k_{l}}}{\frac{F(\bar{k})}{k}} .
$$

The above result indicates that ringleader exclusion allows the cartel to sustain higher prices when three requirements are met. First, the optimal cartel price under a nondiscriminatory leniency policy must lie strictly below the monopoly price. Clearly, if the joint profit maximum can be sustained without ringleader exclusion, then the introduction of a discriminatory

\footnotetext{
${ }^{19}$ Notice that the same logic applies when there is more than one ringleader. In that case it would be sufficient to analyze the impact of ringleader exclusion on the ringleader with the tightest ICC under a nondiscriminatory leniency program.
} 
leniency policy will induce a weakly lower cartel price. Second, the antitrust penalty must depend in a nonlinear fashion on cartel gains. If fines are proportional to firm size, then the RHS of (7) is equal to one whereas the LHS is strictly smaller than one. Finally, the size distribution of firms must be sufficiently heterogeneous. This is because when all firms are of equal size the RHS of (7) is equal to one independent of the shape of the antitrust penalty function.

If we embrace the finding in Section 2 that ringleaders are typically the largest firms, then Theorem 4 supports a proportional or more than proportional fining structure. By Lemma 3, we know that the largest cartel member has the tightest ICC under a nondiscriminatory leniency program when the antitrust penalty function is linear or convex. Thus, in these cases $\bar{k}=k_{1}$ and therefore $(7)$ is violated when $k_{l}=k_{1}$. Yet, in this case ringleader exclusion may still lead to higher prices when the smallest member takes a leading role provided that the fining structure is nonlinear. Consequently, to prevent the potential adverse effect of ringleader exclusion, the above result suggests that an optimal antitrust punishment system prescribes the imposition of fines proportional to firm size.

\subsection{Side-payments}

Thus far, results have been derived for a given profit allocation scheme. However, it is important to note that adopting a different profit sharing rule can be beneficial for the cartel. Provided that the fining structure is nonlinear, it may pay for firms to reallocate profits so as to relax the tightest ICC. Specifically, when the antitrust penalty function is concave (convex) it can be profitable to adopt a less (more) than proportional profit sharing rule. One can imagine that this issue is more pronounced with ringleader exclusion. For example, potential cartel members may be hesitant to take a leading role under a discriminatory leniency policy and will only do so when sufficiently compensated for giving up the right to apply for (full) immunity.

Indeed, in the analysis above we have compared a nondiscriminatory with a discriminatory leniency policy under the assumption that there is a ringleader. Yet, an alternative way of looking at the benchmark is that it describes collusion under a discriminatory leniency regime absent ringleaders. This raises the question of whether and when having a ringleader is beneficial for all cartel members. Given the proportional profit sharing rule, firm $i \in N$ has an incentive to become a ringleader only when

$$
\left(p^{* *}-c\right) D\left(p^{* *}\right) \frac{k_{i}}{K}-\delta \alpha\left(1-\beta_{l}\right) F\left(k_{i}\right)>\left(p^{*}-c\right) D\left(p^{*}\right) \frac{k_{i}}{K}-\delta \alpha(1-\beta) F\left(k_{i}\right) .
$$


Observe that (8) is violated for all $i \in N$ when $p^{* *} \leq p^{*}$. That is, if the presence of a ringleader does not lead to higher prices, then none of the firms has an incentive to take a leading role. In this case, however, assigning a ringleader may still be profitable provided that cartel gains are allocated properly. The question of interest is therefore whether and when the presence of a ringleader generates a higher total cartel value in comparison with the nondiscriminatory benchmark.

To address this question, note that the total collusive value absent a ringleader is

$$
V\left(p^{*}\right)=\frac{\left(p^{*}-c\right) D\left(p^{*}\right)-\delta \alpha(1-\beta) \sum_{i \in N} F\left(k_{i}\right)}{1-\delta(1-\alpha)},
$$

whereas the total cartel value with a ringleader is given by

$$
\begin{array}{r}
V\left(p^{* *}\right)=\frac{\left(p^{* *}-c\right) D\left(p^{* *}\right) \sum_{i \in N \backslash\{l\}} \frac{k_{i}}{K}-\delta \alpha\left(1-\beta_{m}\right) \sum_{i \in N \backslash\{l\}} F\left(k_{i}\right)}{1-\delta(1-\alpha)}+ \\
\frac{\left(p^{* *}-c\right) D\left(p^{* *}\right) \frac{k_{l}}{K}-\delta \alpha\left(1-\beta_{l}\right) F\left(k_{l}\right)}{1-\delta(1-\alpha)}= \\
\frac{\left(p^{* *}-c\right) D\left(p^{* *}\right)-\delta \alpha\left(\left(1-\beta_{m}\right) \sum_{i \in N \backslash\{l\}} F\left(k_{i}\right)+\left(1-\beta_{l}\right) F\left(k_{l}\right)\right)}{1-\delta(1-\alpha)} .
\end{array}
$$

There exists a profit division rule for which assigning a leader makes all firms better off when $V\left(p^{* *}\right)>V\left(p^{*}\right)$. Comparing (10) with (9) gives

$$
\begin{aligned}
& V\left(p^{* *}\right)>V\left(p^{*}\right) \Longleftrightarrow \\
& \left(p^{* *}-c\right) D\left(p^{* *}\right)-\left(p^{*}-c\right) D\left(p^{*}\right)>\delta \alpha\left(\left(\beta-\beta_{l}\right) F\left(k_{l}\right)-\left(\beta_{m}-\beta\right) \sum_{i \in N \backslash\{l\}} F\left(k_{i}\right)\right) .
\end{aligned}
$$

This condition reveals that whether or not side-payments are potentially beneficial essentially depends on the change in the cartel's objective and the change in the total expected antitrust penalty. Specifically, notice that if assigning a ringleader has no effect on the cartel price, then (11) is satisfied only when the decrease in expected discount for the ringleader is more than offset by the increase in expected discount for regular cartel members. Moreover, the RHS of (11) is maximal for $k_{l}=k_{1}$ and therefore is least likely to hold when the intended leader is the largest firm.

To gain some further insight, consider the extreme case where the ringleader and all regular members but the first to self-report are not eligible for leniency. Suppose further that the applicant receives full immunity (i.e., $\beta=\frac{1}{n}, \beta_{m}=\frac{1}{n-1}$ and $\beta_{l}=0$ ). If $p^{* *}=p^{*}$, then $V\left(p^{* *}\right)>V\left(p^{*}\right)$ only when the antitrust penalty of the ringleader is lower than the average fine:

$$
F\left(k_{l}\right)<\frac{\sum_{i \in N} F\left(k_{i}\right)}{n} .
$$


Thus, in this case compensation is a possibility when the ringleader is the smallest firm and not beneficial when the ringleader is the largest firm. In light of the empirical findings in Section

2 , these results suggest that ringleader exclusion seems unlikely to create adverse effects by providing incentives to adopt more complicated profit allocation rules. Ringleaders that have been identified in antitrust practice were typically among the larger firms in the industry. Indeed, at least intuitively one would expect dominant firms to take a central position in the cartel. This also holds with respect to cartel formation as larger firms have usually more to gain from collusion. Furthermore, various empirical cartel studies show that bargaining complexities should not be underestimated. For example, Levenstein and Suslow (2004) state that "Bargaining problems were much more likely to undermine collusion than was secret cheating. About one quarter of the cartel episodes ended because of bargaining problems. Bargaining issues affected virtually every industry studied."

In sum, deviating from a simple and intuitive profit allocation rule is most likely to be beneficial when the intended ringleader is the smallest firm. However, evidence from antitrust practice does not offer much support for this possibility.

\section{Concluding Remarks}

In this study, we have sought to shed light on cartel ringleaders in relation to the corporate leniency program. Depending on the jurisdiction, a ringleader may or may not be eligible to apply for leniency. As not much is known about cartel ringleaders, we have first conducted a survey of recent European cartel cases to identify some common characteristics of ringleaders. The results of this survey reveal that $(i)$ there is often more than one ringleader, $(i i)$ the role of ringleaders is diverse and ( $i i i)$ ringleaders are typically the largest cartel members. Our theoretical analysis shows that ringleader exclusion can create adverse effects. Specifically, disqualifying a cartel ringleader from obtaining leniency can lead to higher collusive prices when $(i v)$ the joint profit maximum is unfeasible under a nondiscriminatory leniency policy, $(v)$ antitrust fines depend on individual cartel gains in a nonlinear fashion and $(v i)$ the size distribution of members is sufficiently heterogeneous.

These results are driven by two main factors. The first is quite general. In comparison to a nondiscriminatory leniency regime, ringleader exclusion tightens the ICC of ringleaders and loosens the ICC of regular cartel members. Given a particular profit allocation rule, the magnitude of these changes determine whether or not the cartel can sustain higher prices. The second is more specific. We have assumed that collusive profits and expected antitrust penalties depend positively on production capacity, which is taken as a proxy for firm size. 
This assumption finds support in antitrust practice. Yet, it is potentially profitable for a cartel to adopt a more complicated profit sharing rule. In this respect, we have shown that assigning a ringleader is most likely to create a higher total cartel value when the intended leader is the smallest firm. From a policy perspective, our overall findings suggest that it is optimal to impose antitrust penalties proportional to firm size when one is willing to exclude cartel ringleaders from the corporate leniency program. 


\section{References}

[1] Aubert, Cécile, Patrick Rey and William E. Kovacic (2006), "The impact of leniency and whistle-blowing programs on cartels," International Journal of Industrial Organization, 24, 1241-1266;

[2] Bigoni, Maria, Sven-Olof Fridolfsson, Chloé Le Coq and Giancarlo Spagnolo (2009), "Fines, Leniency and Rewards in Antitrust: An Experiment," CEPR Discussion Papers, No. DP7417;

[3] Bos, Iwan and Joseph E. Harrington Jr. (2010), "Endogenous Cartel Formation with Heterogeneous Firms," RAND Journal of Economics, 41(1), 92-117;

[4] Ganslandt, Mattias, Lars Persson and Helder Vasconcelos (2010), "Asymmetric Cartels: A Theory of Ringleaders," CEPR Discussion Papers, No. 6829;

[5] Herre, Jesko and Alexander Rasch (2009), "The Deterrence Effect of Excluding Ringleaders from Leniency Programs," Discussion Paper;

[6] Harrington, Joseph E. Jr. (2008), "Optimal Corporate Leniency Programs," Journal of Industrial Economics, 56(2), 215-246;

[7] Ishibashi, Ikuo (2008), "Collusive Price Leadership with Capacity Constraints," International Journal of Industrial Organization, 26, 704-715;

[8] Leslie, Christopher R. (2006), "Antitrust Amnesty, Game Theory, and Cartel Stability," Journal of Corporation Law, 31, 453-488;

[9] Levenstein, Margaret C. and Valerie Y. Suslow (2004), "Studies of Cartel Stability: A Comparison of Methodological Approaches," in: Grossman, Peter Z., How Cartels Endure and How they Fail, Cheltenham, U.K.: Edward Elgar Publishing, 2004;

[10] Marshall, Robert C., Leslie M. Marx and Lily Samkharadze (2011), "Dominant-Firm Conduct by Cartels," Discussion Paper;

[11] Miller, Nathan H. (2009), "Strategic Leniency and Cartel Enforcement," American Economic Review, 99(3), 750-768;

[12] Motchenkova, Evgenia and Daniel Leliefeld (2007), "To Protect in order to Serve, adverse effects of leniency programs in view of industry asymmetry," TILEC Discussion Papers, Series 2007-007; 
[13] Motta, Massimo and Michele Polo (1999), "Leniency Programs and Cartel Prosecution," European University Institute Working Paper, No. 99/23;

[14] Motta, Massimo and Michele Polo (2003), "Leniency Programs and Cartel Prosecution," International Journal of Industrial Organization, 21(3), 347-379;

[15] Mouraviev, Igor and Patrick Rey (2011), "Collusion and Leadership," International Journal of Industrial Organization, forthcoming;

[16] Spagnolo, Giancarlo (2000), "Optimal Leniency Programs," FEEM Working Paper, No. 42.2000 ;

[17] Spagnolo, Giancarlo (2008), "Leniency and Whistleblowers in Antitrust," in: Buccirossi, P., Handbook of Antitrust Economics, Cambridge, MA.: MIT Press, 2008. 